\title{
Experimental Pulmonary Inflammatory Injury in the Monkey
}

\author{
Susan D. Revak, Charles L. Rice, Ingrid U. Schraufstätter, Wayne A. Halsey, Jr., Benjamin P. Bohl, \\ Robert M. Clancy, and Charles G. Cochrane \\ Department of Immunology, Scripps Clinic and Research Foundation, La Jolla, California 92037; and Department of Surgery, \\ Harborview Medical Center, Seattle, Washington 98104
}

\begin{abstract}
Inflammatory pulmonary injury was induced in Macacca mulatta rhesus monkeys by the intrabronchial instillation of the formylated peptide norleu-leu-phe (FNLP) or phorbol myristate acetate (PMA). Indicators of pulmonary injury included an increase in mean protein content of bronchoalveolar lavage (BAL) fluid from $0.51 \mathrm{mg} / \mathrm{ml}$ in untreated animals to $3.74 \mathrm{mg} / \mathrm{ml}$ and $6.64 \mathrm{mg} / \mathrm{ml}$ in FNLP- and PMA-treated animals, respectively, the appearance of a diffuse pulmonary infiltrate in chest roentgenograms, and histologic evidence of a predominantly neutrophilic leukocytic infiltration.
\end{abstract}

Concomitant with the appearance of pulmonary injury was the generation of proteases and oxidants in the BAL fluids. Neutrophil elastase, bound to $\alpha_{1}$-protease inhibitor ( $\left.\alpha_{1}-\mathrm{PI}\right)$, was found to increase from $0.47 \mu \mathrm{g} / \mathrm{ml}$ in untreated monkeys to $0.99 \mu \mathrm{g} /$ $\mathrm{ml}$ in FNLP-treated animals and $1.23 \mu \mathrm{g} / \mathrm{ml}$ in monkeys receiving PMA. Radioiodinated human prekallikrein, instilled for 2 min into the inflammatory site and retrieved by lavaging, was found to have undergone proteolytic cleavage; this cleavage was not consistently inhibitable with the inclusion of antibody to elastase. BAL fluids were shown to contain an amidolytic activity when tested on the synthetic substrate $H$-D-pro-phe-arg-pNA. This activity was partially inhibitable with known inhibitors of active Hageman factor and kallikrein. $\beta$-Glucuronidase levels in the BAL fluids increased from $0.85 \mathrm{U} / \mathrm{ml}$ to $4.36 \mathrm{U} / \mathrm{ml}$ and 8.25 $\mathrm{U} / \mathrm{ml}$ in FNLP- and PMA-treated animals, respectively. Myeloperoxidase (MPO) levels also increased from 1.37 OD $\mathrm{U} / \mathrm{ml} \cdot \mathrm{min}$ to 16.59 and $30.47 \mathrm{OD} \mathrm{U} / \mathrm{ml} \cdot \mathrm{min}$ in the same groups of animals.

Oxidant generation was also assessed in several different ways. The specific activity of the oxidant-sensitive inhibitor $\alpha_{1-}$ PI recovered in the BAL fluid decreased from 0.80 in control samples to 0.57 and 0.65 in FNLP- and PMA-treated animals. That this inactivation was due to oxidant injury of the molecule was confirmed by the return to full activity of four out of five BAL samples after their incubation with the reducing agent dithiothreitol in the presence of methionine sulfoxide peptide reductase. The specific activity of catalase in the BAL fluids of animals given 3-amino, 1,2,4 triazole (AT) $1 \mathrm{~h}$ before lavaging showed drops from 0.97 in untreated monkeys to 0.04 in FNLPtreated and 0.49 in PMA-treated monkeys. MPO levels also fell in the AT-treated injured animals from 16.59 to $0.85 \Delta \mathrm{OD} /$

Dr. Rice is with the Harborview Medical Center, Seattle, WA.

This is Publication No. 3691-IMM from the Research Institute of the Scripps Clinic.

Received for publication 6 November 1984 and in revised form 1 April 1985

J. Clin. Invest.

(c) The American Society for Clinical Investigation, Inc.

$0021-9738 / 85 / 09 / 1182 / 11 \quad \$ 1.00$

Volume 76, September 1985, 1182-1192 $\mathrm{min} \cdot \mathrm{ml}$ in FNLP animals in the absence and presence of $\mathrm{AT}$, and 30.47 to $0.60 \Delta O D / \mathrm{min} \cdot \mathrm{ml}$ in PMA-treated animals. Inhibition of MPO by AT was shown in vitro to be $\mathrm{H}_{2} \mathrm{O}_{2}$ dependent. Total glutathione levels in the BAL fluids did not change appreciably after FNLP or PMA treatment.

These studies present substantial evidence of the generation of both proteases and oxidants during the establishment of acute pulmonary inflammatory injury in an experimental primate model.

\section{Introduction}

Both proteases and oxidants may play important roles in the development of pulmonary inflammatory injury. Both have been detected in vivo in human disease and in models of pulmonary inflammation in experimental animals (1-13). Recent studies have revealed the presence of neutrophilic elastase in bronchoalveolar lavage (BAL) ${ }^{1}$ fluids from patients with respiratory distress syndrome and other inflammatory conditions $(3,6,10)$. Neutrophilic acid proteases and other leukocytic enzymes were found in BAL fluids from rabbits undergoing experimentally induced pulmonary inflammation (13).

Oxidant activity in situ has been measured indirectly. In human beings with pulmonary inflammation, evidence for the generation of oxidants in the bronchoalveolar region has been provided by analysis of $\alpha_{1}$-proteinase inhibitor $\left(\alpha_{1}-\mathrm{PI}\right) . \alpha_{1}-\mathrm{PI}$ is known to lose inhibitory activity for proteases when a methionyl residue in the active site is converted to methionyl sulfoxide (14-16). In vitro studies have shown that human $\alpha_{1}$-PI can become inactivated in the presence of halide and phorbol myristate acetate (PMA)-stimulated human neutrophils, presumably through the oxidative action of the myeloperoxidase (MPO)hydrogen peroxide system (17). In the respiratory distress syndrome of adults and premature infants, $\alpha_{1}-\mathrm{PI}$ in BAL fluids was found to be in great part inactive $(3,6,9,10)$, and the activity of the $\alpha_{1}$-PI could be restored by treatment with methionyl sulfoxide peptide reductase in the presence of dithiothreitol (DTT) (9). Oxidative inactivation of the elastase inhibitory capacity of $\alpha_{1}$-PI may also play a critical role in the pathogenesis of emphysema $(18,19)$.

Oxidant generation and oxidant-mediated injury have been documented in experimental animal systems as well. In rabbits, extracellular catalase in inflamed lungs was inhibited by 3-amino, $1,2,4$ triazole (AT), which can occur only when $\mathrm{H}_{2} \mathrm{O}_{2}$ is present

1. Abbreviations used in this paper: $\mathrm{ACE}$, angiotensin converting enzyme; $\alpha_{1}$-PI, $\alpha_{1}$-protease inhibitor; AT, 3-amino, 1,2,4 triazole; BAL, bronchoalveolar lavage; CT, chloramine T; DTT, dithiothreitol; ELISA, enzyme-linked immunosorbent assay; FNLP, formyl-norleu-leu-phe; HNE, human neutrophil elastase; HSA, human serum albumin; MNE, monkey neutrophil elastase; MPO, myeloperoxidase; MS, methionine sulfoxide; NMP, normal monkey plasma; PK, prekallikrein; PMA, phorbol myristate acetate; SBTI, soybean trypsin inhibitor; SDS, sodium dodecyl sulfate. 
(20-23), and this inhibition was prevented by the use of antioxidant or by neutrophil depletion (13). A marked fall in intracellular glutathione, a major defender against oxidants, was also found in these animals, and was likewise preventable by antioxidant or neutrophil depletion (13). In rats, inactivators of $\mathrm{H}_{2} \mathrm{O}_{2}$, scavengers of oxygen free radicals, and chelation of $\mathrm{Fe}^{3+}$ (to prevent formation of hydroxyl radicals), all inhibited the development of pulmonary edema and injury of endothelial cells (8, $11,12)$. In other studies, perfusion of stimulated normal human neutrophils into the vasculature of in vitro perfused rabbit lungs produced vascular injury, while similar treatment with neutrophils of patients with chronic granulomatous disease were without effect (7).

Although information regarding the biochemical aspects of the inflammatory process may be obtained from studies in rodents and rabbits, many biochemical facets of their plasma proteins and inflammatory cells are dissimilar to those of human beings. We have therefore conducted studies on the development of inflammatory pulmonary disease in subhuman primates. In particular, we have measured the presence or generation in situ of nonleukocytic and leukocytic proteases such as neutrophilelastase, leukocytic oxidants, arachidonate metabolites, angiotensin-converting enzyme, and components of the complement and contact system. The relationship of the concentrations or presence of these mediators in the lung and inflammatory injury will be assessed. The primate model also provides a system for future studies on the use of therapeutic agents for blocking or controlling specific components of the inflammatory process.

\section{Methods}

\section{Proteins and antibodies}

Human prekallikrein (PK) was a gift from Dr. Yoshio Hojima of our laboratory and was radiolabeled by the chloramine T (CT) method (24) to a specific activity of $10 \mu \mathrm{Ci} / \mu \mathrm{g}$. Antisera to human neutrophilic elastase was prepared in our laboratory as described previously (6) and was found to crossreact with elastase from rhesus monkey neutrophil granules. $\alpha_{1-}$ PI was isolated from monkey plasma using the methods developed for human $\alpha_{1}$-PI purification (9) and antisera was produced in a goat by biweekly multiple intradermal injections of $60 \mu \mathrm{g}$ protein in minced acrylamide gel plus complete Freund's adjuvant (Difco Laboratories, Detroit, MI). Antibody produced after $10 \mathrm{wk}$ showed a single coalescent line in double immunodiffusion tests with monkey plasma and purified monkey $\alpha_{1}$-PI.

Human catalase was prepared by a method based on that of Stansell and Deutsch (25). Human erythrocytes sedimented through gelatin were washed three times with 0.9 percent $\mathrm{NaCl}$ at room temperature. Washed cells were stored frozen at $-20^{\circ} \mathrm{C}$ until used (1 wk). $900 \mathrm{ml}$ of packed cells was lysed by adding an equal volume of $0.2 \%$ saponin in cold water and stirring at $4^{\circ} \mathrm{C}$ for $1 \mathrm{~h}$. The lysate was dialyzed against $3 \mathrm{mM}$ sodium potassium phosphate, pH 7.0 ("starting buffer"), and then added to 750 ml of DEAE-Sephacel beads (Pharmacia, Uppsala, Sweden). After shaking for $1 \mathrm{~h}$ at $4^{\circ} \mathrm{C}$, the mixture was poured into a scintered glass funnel and washed until the red color was reduced to light pink. The gel was then packed in a $5 \times 28-\mathrm{cm}$ column and washing with starting buffer continued until $\mathrm{OD}_{280}=0.050$. Proteins were then eluted with a gradient of 2 liters each of starting buffer and starting buffer $+0.2 \mathrm{M} \mathrm{NaCl}$. Catalase was eluted from 6 to $8 \mathrm{mmho}$. The region was pooled and brought to $50 \%$ saturation with solid ammonium sulfate. Proteins precipitating at this concentration were discarded and the supernatant brought to $70 \%$ saturation with ammonium sulfate. The proteins precipitated at this concentration were dialyzed against $0.01 \mathrm{M}$ sodium acetate, $\mathrm{pH}$ 5.0, and then applied to a column containing $230 \mathrm{ml}$ of SP-Sephadex C-50. The column was washed at a flow rate of $90 \mathrm{ml} / \mathrm{h}$ and then eluted with a gradient of 2 liters each of $0.01 \mathrm{M}$ acetate, $\mathrm{pH} 5.0$ (0.9 mmho), and 0.01
M acetate plus $0.4 \mathrm{M} \mathrm{NaCl}$ (35 mmho). Three overlapping peaks of catalase activity were found eluting from 9.4 to $23 \mathrm{mmho}$. Catalase in the three peaks could not be distinguished by electrophoresis or by gel filtration. In the presence of mercaptoethanol, all showed $>95 \%$ homogeneity in a band at $\sim 60,000$ mol wt. Analysis on G-150 gel filtration resulted in a mol wt of 110,000 . A total of $137 \mathrm{mg}$ of human catalase was recovered. Antibody to human catalase was produced in rabbits by the weekly subcutaneous injection into multiple sites of $100 \mu \mathrm{g}$ of purified protein in complete Freund's adjuvant. Monospecific antibody, produced by the fourth week, was found to crossreact with catalase from monkey erythrocytes.

\section{Reagents}

Formyl-norleu-leu-phe (FNLP) (Vega, Tucson, AZ) was dissolved 50 $\mathrm{mg} / \mathrm{ml}$ in dimethyl sulfoxide and stored at $-20^{\circ} \mathrm{C}$ until used. PMA (Midland Corp., Brewster, NJ) was dissolved $10 \mathrm{mg} / \mathrm{ml}$ in dimethyl sulfoxide and stored in the dark at $-70^{\circ} \mathrm{C}$ until used. AT (Sigma Chemical Co., St. Louis, MO) was dissolved in saline at a concentration of 100 $\mathrm{mg} / \mathrm{ml}$ just before use. Human serum albumin (HSA) was from Armour Pharmaceutical Company (“Albuminar-25”, Kankakee, IL).

\section{Experimental protocol}

Rhesus monkeys, Macacca mulatta, 6-10 kg were used in these studies. All animals were cared for according to the principles of the Guide for the Care and Use of Laboratory Animals, ${ }^{2}$ and were under the continuous care of a veterinarian. Anesthesia was induced with ketamine hydrochloride (Parke-Davis, Morris Plains, NJ) $8-10 \mathrm{mg} / \mathrm{kg}$ intravenously, and maintained with $3-5 \mathrm{mg} / \mathrm{kg}$ every $2 \mathrm{~h}$ until the completion of the experiment. The animals were intubated with a cuffed 6 Fr. orotracheal tube.

Preliminary experiments were performed in both rabbits (13) and monkeys to determine what inciting agents would yield reproducible, nonlethal, localized inflammatory injury. Two leukocytic stimuli, FNLP and PMA, were chosen. Both have been shown in numerous studies to be chemoattractants, to cause aggregation of polymorphonuclear leukocytes (PMNs) and release of oxidants and proteases, and to cause lung injury when used in vivo $(7,13,26-33)$. Optimal doses and times of lavage sampling were likewise determined in preliminary experiments. $200 \mu \mathrm{g} / \mathrm{kg} \mathrm{FNLP}$, instilled intrabronchially, was found to cause a moderate infiltration of PMNs into the lung after $5 \mathrm{~h}$. Because $<10 \%$ of the formyl peptide is present in lung tissue at that time (13), a second dose of FNLP was given at $5 \mathrm{~h}$ to induce the release of oxidants and proteases from the accumulated cells that would be measured in lavage samples taken $1 \mathrm{~h}$ later. Intrabronchial instillation of $10 \mu \mathrm{g} / \mathrm{kg}$ PMA was found to cause a more rapid and severe leukocytic infiltration. This second stimulus was used to determine whether a different response of mediator systems could be detected. Fig. 1 shows a typical infiltration of leukocytes and the interstitial edema seen after PMA challenge.

Standard anterior-posterior chest radiographs were obtained and reviewed before beginning the experiment. Blood was drawn from the femoral artery into citrate for cell counts, hematocrit, and plasma samples. $5 \mathrm{ml}$ of blood was centrifuged and $2 \mathrm{ml}$ of plasma was frozen immediately. Two pulmonary lavages were performed on each animal as described below. The recovered BAL fluids, referred to as the "untreated" samples throughout this paper, served as controls for each animal. Pulmonary injury was then induced by one of two means: FNLP, $200 \mu \mathrm{g} / 2 \mathrm{ml}$ per $\mathrm{kg}$ in saline or PMA, $10 \mu \mathrm{g} / 2 \mathrm{ml}$ per $\mathrm{kg}$, in saline containing $0.01 \%$ Evan's Blue dye plus $0.01 \%$ HSA was instilled intrabronchially above the carina with the animals held in an upright position. After $4.5 \mathrm{~h}$, $\mathrm{x}$ rays were again taken of the animals that received FNLP. AT in saline, in a concentration of $1 \mathrm{~g} / 10 \mathrm{ml}$ per $\mathrm{kg}$ or saline alone $(10 \mathrm{ml} / \mathrm{kg})$ was administered intraperitoneally. A second intrabronchial instillation of FNLP (same dose as first time) was then made, incorporating $0.01 \%$

2. Department of Health, Education and Welfare Publication (NIH) 7823, revised 1978, Office of Science and Health Reports, DRR/NIH, Bethesda, MD 20205. 


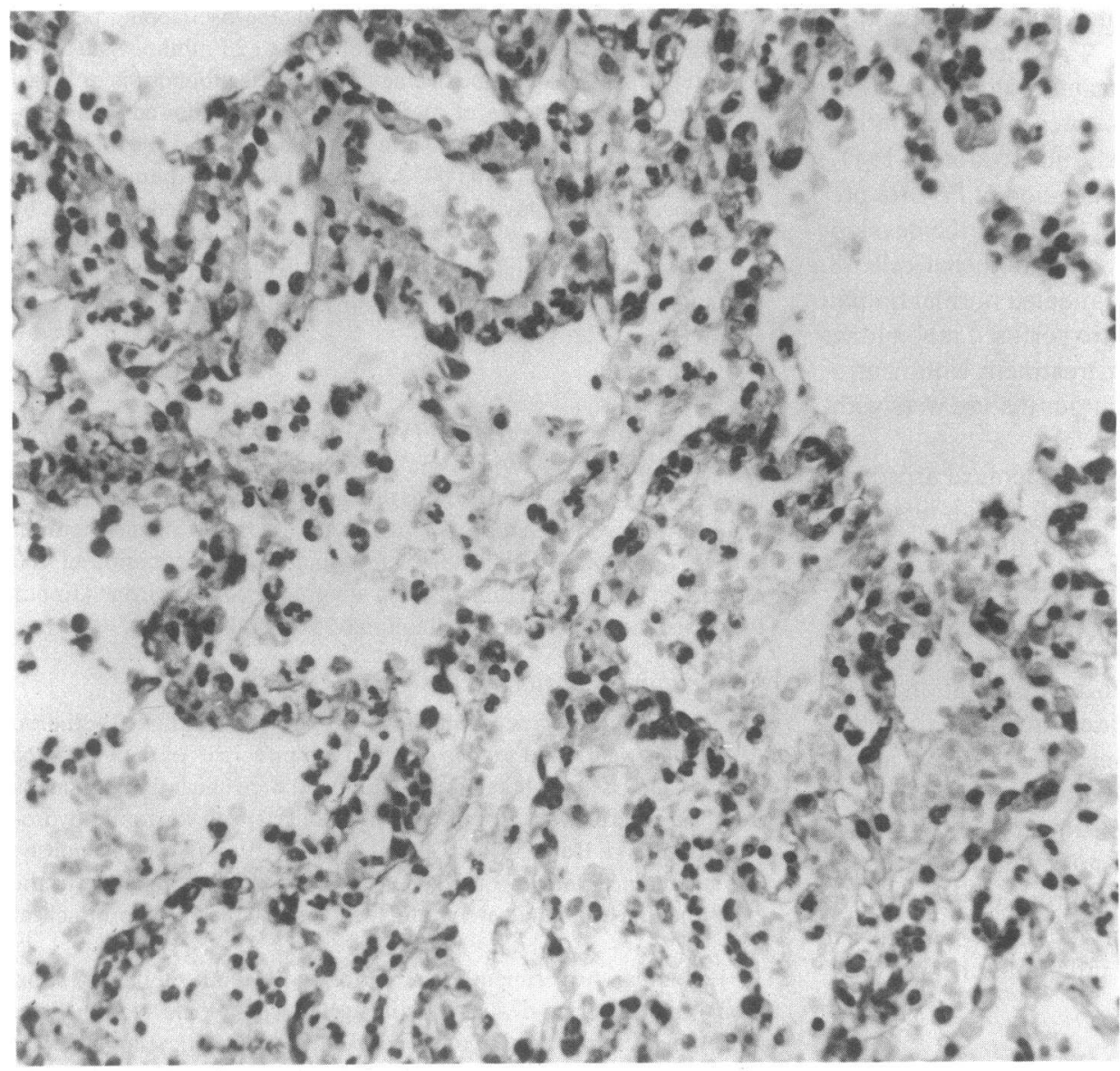

Figure 1. Photomicrograph of the lung of a rhesus monkey obtained $5 \mathrm{~h}$ after instillation of PMA. Accumulation of neutrophils in alveolar septae and spaces are apparent along with amorphous material with tinctorial characteristics of edema fluid. $\times 156$.

Evan's Blue-HSA. $1 \mathrm{~h}$ later ( $5.5 \mathrm{~h}$ after the first FNLP instillation) terminal laváges and blood samples were taken. PMA-challenged animals were $\mathrm{x}$-rayed and given AT or saline intraperitoneally $3 \mathrm{~h}$ after injury. Terminal samples of blood and BAL fluids were taken $1 \mathrm{~h}$ later. Control animals were treated identically to the FNLP animals except that FNLP was omitted from the instillation fluid and neither AT nor saline was given intraperitoneally.

Lavage procedure (untreated, e.g., preinjury, samples): 2 min before lavage, $2 \mathrm{ml}$ of saline containing $100 \mu \mathrm{g} / \mathrm{ml} \mathrm{HSA}$ and $7.1 \mu \mathrm{Ci}{ }^{125} \mathrm{I}-\mathrm{PK}$ were iństilled via a soft-tipped cannula passed through the endotracheal tube into the lower respiratory tract and advanced until wedged. The cannula was left in place for $2 \mathrm{~min}$ and then $15 \mathrm{ml}$ of saline was instilled and immediately recovered. Because of the low volumes of recovery in normal, nonedematous lungs, a second $15-\mathrm{ml}$ lavage was often done in the same site. The volume recovered was recorded and $0.5-\mathrm{ml}$ samples were added to $0.5 \mathrm{ml}$ of methánol or $0.5 \mathrm{ml}$ isopropanol and frozen immediately on dry ice for later analysis of leukotrienes $B_{4}$ and $C_{4} / D_{4}$, respectively. The remainder of the lavage fluid was centrifuged in 1.5$\mathrm{ml}$ capacity polypropylene tubes for $5 \mathrm{~s}$ in a Beckman Microfuge B (Beckman Instruments, Inc., Palo Alto, CA) adding sequential 1.5-ml aliquots to the same tube until all the sample had been centrifuged. The supernatant BAL fluids were frozen immediately on dry ice. To lyse and remove any contaminating erythrocytes, the cell pellet was resuspended in $25 \mu \mathrm{l}$ of Hanks' buffer. (If two lavages had been done in the same site, the two cell pellets were combined at this point.) $1 \mathrm{ml}$ of cold distilled water was added and the sample mixed continually for $30 \mathrm{~s}$ while being kept on wet ice. Isotonicity was then restored with $333 \mu \mathrm{l}$ of $3.5 \% \mathrm{NaCl}$. The tubes were centrifuged for $5 \mathrm{~s}$; then the supernatant was removed and discarded. $500 \mu \mathrm{l}$ of distilled water was added to the cell pellet and the sample was frozen on dry ice for later analysis. The terminal lavage procedure differed only as follows: After the initial lavage was taken ( 2 min after ${ }^{125}$ I-PK instillation), a second cannula was inserted through the endotracheal tube into a different lobe; the first cannula was then removed. $2 \mathrm{ml}$ of saline containing $100 \mu \mathrm{g} / \mathrm{ml} \mathrm{HSA}, 7.1 \mu \mathrm{Ci}{ }^{125} \mathrm{I}-\mathrm{PK}$ and $55 \mu \mathrm{l}$ of immunopurified anti-human neutrophil elastase (HNE) were instilled. 2 min later a $15-\mathrm{ml}$ saline lavage was performed. The two samples thus obtained were processed as above, only the washed cell pellets as well as the supernatants were kept separate. Animals given PMA had their terminal lavages performed with $7.5 \mathrm{ml}$ of saline instead of $15 \mathrm{ml}$.

Pathophysiologic changes in the lungs were difficult to assess in the monkeys because, in order to retain the animal for further experiments, injury was limited to a segment of one lobe. Hence it was not possible to carry out analyses of lung weight or functional assays such as changes in $\mathrm{PO}_{2}$ and $\mathrm{PCO}_{2}$. Although these latter were attempted, changes were minimal and varied greatly with the time after administration of ketamine. Resistance and compliance assays were not attempted owing to the limited zone of injury. To assess the presence of inflammation, we therefore performed open biopsies at 3 and $6 \mathrm{~h}$ on the PMA- and FNLP-treated monkeys, respectively, and at $24 \mathrm{~h}$ in both groups. Untreated control monkeys were also biopsied. In addition, radiographs were taken at the same times noted above, as well as measurement of total protein and cells in the BAL fluid taken at the same times. It was also interesting that the volume of lavage fluid aspirated after instillation of saline solution was greater in injured lungs as noted below. Nevertheless, one of the drawbacks of these studies in living primates is the lack of quantitative estimates of lung damage.

Protein. Protein contents of plasma, BAL fluid, and cell pellets were measured by the method of Lowry et al. (34).

Enzyme assays. Catalase activity in BAL samples was measured by the method of Aebi (35) by following the disappearance of $\mathrm{H}_{2} \mathrm{O}_{2}$ spectrophotometrically. MPO was measured as follows: Wells of a flat-bottom 96-well microtiter plate were filled with $50 \mu \mathrm{l}$ of sample in $0.1 \mathrm{M}$ citrate buffer, $\mathrm{pH}$ 4.2. $50 \mu \mathrm{l}$ of citrate buffer containing $1 \mathrm{mM}$ 2,2'-azino-di-(3ethylbenzthiazoline sulfonic acid) (ABTS, Sigma Chemical Co., St. Louis, 
MO) and $0.03 \% \mathrm{H}_{2} \mathrm{O}_{2}$ was added. Absorbance at $414 \mathrm{~nm}$ was read at two time points within the first 15 min on a Titertek Multiskan photometer (Flow Laboratories, McLean, VA) and the data were expressed as the change in optical density per minute per milliliter of sample. $\beta$-Glucuronidase was assayed by a modification of a previously described method (36): In 1.5-ml polypropylene tubes, $20 \mu$ l of sample or standards (0.05-0.6 U standard $\beta$-glucuronidase, Calbiochem-Behring Corp., La Jolla, CA) were added to $30 \mu \mathrm{l}$ of $0.1 \mathrm{M}$ acetate buffer, $\mathrm{pH} 4.5 .50 \mu \mathrm{l}$ of phenolphthalein glucuronide (Sigma Chemical Co.), $1.3 \mathrm{mg} / \mathrm{ml}$ in acetate buffer, was added and the tubes were capped and incubated overnight at $37^{\circ} \mathrm{C}$. The reaction was stopped and developed with the addition of $100 \mu \mathrm{l}$ of $0.5 \mathrm{M}$ glycine- $\mathrm{NaOH}$ buffer, $\mathrm{pH}$ 10.7. The samples were transferred to a 96-well flat-bottom microtiter plate and absorbance at 540 $\mathrm{nm}$ read on a Titertek Multiskan (Flow Laboratories). A linear relationship existed between the absorbance and the amount of $\beta$-glucuronidase added. Amidolytic activity was measured using a final concentration of $100 \mathrm{nM} H$-D-pro-phe-arg-pNA (S2302, Kabi Diagnostica, Stockholm, Sweden) in $0.1 \mathrm{M}$ tris buffer $\mathrm{pH}$ 8.0. Samples were incubated with the substrate for $30 \mathrm{~min}$ at $37^{\circ} \mathrm{C}$ and the reaction stopped with $1 \mathrm{~N}$ acetic acid. Absorbance at $405 \mathrm{~nm}$ was read and the data were expressed as the change in absorbance per hour per $50 \mu \mathrm{l}$ of samples. Corn inhibitor, used in these studies as a specific inhibitor of active Hageman factor (37) was a gift from Dr. Yoshio Hojima of this laboratory. Soybean trypsin inhibitor (SBTI, Worthington Biochemical Corp., Freehold, NJ) was used as a kallikrein inhibitor.

\section{Immunologic assays}

Levels of monkey $\alpha_{1}$-PI protein were determined by the radial immunodiffusion method of Mancini et al. (38) using antisera prepared as described above. Catalase levels were determined by an enzyme-linked immunosorbent assay (ELISA) utilizing an antibody to human catalase that exhibited good crossreactivity with the monkey protein, performed as follows: 96-well flat-bottom polystyrene microtiter plates (Nunc Immuno Plate II, Thomas Scientific, Philadelphia, PA) were used for these assays. $50 \mu \mathrm{l}$ of immunopurified rabbit anti human catalase $\mathrm{F}\left(\mathrm{Ab} \mathrm{b}^{\prime}\right)_{2}$ antibodies absorbed with Protein A-Sepharose beads (Pharmacia, Uppsala, Sweden) to remove Fc fragments and residual intact IgG and diluted to $20 \mu \mathrm{g} / \mathrm{ml}$ in phosphate-buffered saline (PBS) were placed into each well. The plate was covered and incubated overnight at $4^{\circ} \mathrm{C}$ on an orbital rocker (Nutator, McGaw Park, IL) to coat the wells. The plate was emptied, and each well washed with $150 \mu \mathrm{l}$ of $2 \%$ bovine serum albumin (BSA, Sigma Chemical Co.) in PBS followed by four washes of PBS alone. $50 \mu$ l of standards ranging from 0 to $0.6 \mu \mathrm{g} / \mathrm{ml}$ purified human catalase or $50 \mu \mathrm{l}$ of unknown samples was added to each well. The plate was incubated on the Nutator for at least $1 \mathrm{~h}$ and washed with BSA and PBS as above. $50 \mu \mathrm{l}$ of immunopurified IgG rabbit anti-human catalase diluted in $0.1 \%$ BSA in PBS was added to each well. After a minimum incubation period of $20 \mathrm{~min}$ at room temperature, the plate was again washed with BSA and PBS. $50 \mu \mathrm{l}$ of a 1:200 dilution in 2\% BSA/PBS of Protein A-glucose oxidase (made by the addition of $10 \mathrm{mg}$ of glucose oxidase to $4 \mathrm{mg}$ of protein $\mathrm{A}$ ) was then added to each well. After a 30min incubation on the Nutator at room temperature, the wells were emptied and washed eight times with PBS. To each well was then added $100 \mu \mathrm{l}$ of a substrate solution consisting of $4 \mathrm{mg}$ of ophenylene diamine,

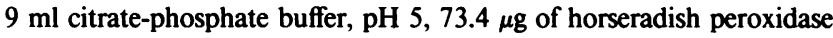
and $1.1 \mathrm{ml}$ of $18 \%$ glucose. The plate was incubated, uncovered, in the dark for up to $2 \mathrm{~h}$ at room temperature until a dark yellow color developed in the most concentrated standards. The reaction was stopped by the addition of $100 \mu \mathrm{l}$ of $5 \mathrm{~N} \mathrm{H}_{2} \mathrm{SO}_{4}$ to each well. The plate was read on the Titertek Multiskan using a filter of $492 \mathrm{~nm}$. A linear relationship existed between the concentration of catalase and the absorbance.

Concentrations of monkey neutrophil elastase (MNE) complexed with $\alpha_{1}$-PI were also determined by an ELISA assay. Standards were made by taking a known quantity of monkey elastase and complexing it completely with monkey $\alpha_{1}-\mathrm{PI}$. Data were expressed as $\mu \mathrm{g} / \mathrm{ml}$ of complexed MNE. Plates, incubations, volumes, washes, and reading of the plate are as described above. The reagents used for the MNE- $\alpha_{1}-\mathrm{PI}$ assay were $(a)$ immunopurified rabbit anti human neutrophil elastase $\mathrm{F}\left(\mathrm{Ab}^{\prime}\right)_{2}$ absorbed with insolubilized Protein-A and diluted to $10 \mu \mathrm{g} / \mathrm{ml}$ with PBS, (b) standard complexes ranging from 20 to $150 \mathrm{ng} / \mathrm{ml} \mathrm{MNE}$ or BAL fluids to be tested, $(c)$ immunopurified goat anti-human $\alpha_{1}-\mathrm{PI},(d)$ rabbit anti-goat Fc fragment (Cappel Laboratories, West Chester, PA) diluted 1/50, (e) Protein A-glucose oxidase, $(f)$ substrate solution, $(g) 5 \mathrm{~N} \mathrm{H}_{2} \mathrm{SO}_{4}$ to terminate the reaction. A linear relationship existed between the absorbance at $492 \mathrm{~nm}$ and the log of the amount of complexed monkey elastase.

$\alpha_{I}$-PI activity. $\alpha_{1}$-PI activity in the monkey plasmas and BAL fluids was measured by inhibition of porcine pancreatic elastase (Sigma Chemical Co.) (39). A pool of normal monkey plasma (NMP) containing 1.3 $\mathrm{mg} / \mathrm{ml} \alpha_{1}$-PI was used as a standard. Reactivation of oxidized $\alpha_{1}$-PI in the presence of the reducing agent dithiothreitol (DTT, Sigma, St. Louis, $\mathrm{MO}$ ) and methionine sulfoxide (MS) peptide reductase (kindly provided by Dr. Nathan Brot, Hoffmann-La Roche, Inc., Nutley, NJ) was performed as described previously (9), based on the method of Abrams et al. (40). In the current studies, a single incubation time of $2 \mathrm{~h}$ at $37^{\circ} \mathrm{C}$ was used, with triplicate samples containing DTT, DTT plus MS reductase, or sample + buffer being analyzed.

Glutathione. Total glutathione (reduced and oxidized) was determined by following spectrophotometrically the disappearance of NADPH in the presence of glutathione reductase and 5,5'-dithiobis (2-nitrobenzoic acid) (41).

Cleavage of ${ }^{125} I-P K$. To measure in situ protease activity, ${ }^{125} \mathrm{I}-\mathrm{PK}$ was instilled 2 min before lavage as described above under Experimental protocol. Aliquots of BAL fluids were counted and sample volumes containing equal quantities of ${ }^{125}$ I were applied to $9 \%$ polyacrylamide gels containing $0.1 \%$ sodium dodecyl sulfate (SDS) (42). All samples were run both with and without reduction with $\beta$-mercaptoethanol. After electrophoresis, the gels were fixed, stained, and dried, and visualization of the position of the radiolabel obtained by autoradiography using $X$ Omat AR film (Eastman Kodak XAR-5, Rochester, NY). Quantitation of the cleavage of the ${ }^{125} \mathrm{I}-\mathrm{PK}$ is described in the Results section.

Leukotrienes. Analyses for leukotrienes $\mathrm{LTB}_{4}, \mathrm{LTC}_{4}$, and $\mathrm{LTD}_{4}$ were performed as described (43).

Angiotensin-converting enzyme (ACE). A fluorometric assay (44) was used, employing porcine ACE (Calbiochem-Behring Corp.) as a standard. Data are expressed as nanomoles L-histadyl-L-leucine converted per minute per milliliter of sample.

In vitro inhibition of MPO by AT in the presence of $\mathrm{H}_{2} \mathrm{O}_{2}$. To determine whether inhibiton of MPO activity by AT was $\mathrm{H}_{2} \mathrm{O}_{2}$ dependent, a system similar to that described by Cohen and Hochstein (45) was developed which allowed a slow and continuous diffusion of $\mathrm{H}_{2} \mathrm{O}_{2}$ into a mixture of MPO plus AT. $250 \mu \mathrm{l}$ of $30 \% \mathrm{H}_{2} \mathrm{O}_{2}$ (Fisher Scientific Co., Tustin, CA) was placed into a $1.5-\mathrm{ml}$ capacity conical, plastic micro tube (Sarstedt, Princeton, $\mathrm{NJ}$ ) which had had its cap removed. The $\mathrm{H}_{2} \mathrm{O}_{2}$ tube was placed into a $20-\mathrm{ml}$ capacity polyethylene scintillation vial (American Scientific Products, Irvine, CA). $49.5 \mathrm{mU} / 500 \mu$ l of purified human MPO (Behring Diagnostics, La Jolla, CA) in $1 \mathrm{mg} / \mathrm{ml}$ BSA in Tris-buffered saline was added to the scintillation vial along with $50 \mu \mathrm{l}$ of either water or $250 \mathrm{mM}$ AT. The vial was capped and allowed to incubate for $2 \mathrm{~h}$ in a shaking $37^{\circ}$ water bath. The $\mathrm{H}_{2} \mathrm{O}_{2}$ containing tube was then removed and the solution assayed for its MPO activity as described above. The system was found to result in the diffusion of $\sim 1 \mu \mathrm{mol}$ of $\mathrm{H}_{2} \mathrm{O}_{2}$ (measured by the method of Hyslop and Sklar [46]) into the $500 \mu$ l sample per hour.

Cell counts were performed by standard clinical methods.

Statistical analyses were performed by the use of Student's two-tailed $t$ tests.

\section{Results}

Assessment of injury produced by instillation of formylated peptide (FNLP) and phorbol ester (PMA)

Several methods were used to determine the presence of inflammatory injury. The protein content of each BAL fluid was mea- 
sured as an index of transudation of protein from the vascular space into the pulmonary tissue. 27 lavage samples taken from 16 monkeys before the administration of the injurious agent had a mean protein level of $0.51 \mathrm{mg} / \mathrm{ml} .1 \mathrm{~h}$ after the second instillation of FNLP, the mean protein content was $3.74 \mathrm{mg} /$ ml. Protein in lavages taken $3 \mathrm{~h}$ after treatment with PMA had a mean level of $6.64 \mathrm{mg} / \mathrm{ml}$ (see Table I). These statistically significant $(P<0.001)$ increases were not seen in the control animals that had a mean 6-h protein level of $0.85 \mathrm{mg} / \mathrm{ml}(P$ $=0.3$ ). A qualitative indicator of pulmonary edema was found in the recovery volumes of lavage fluid. Expressed as milliliter of fluid recovered per milliliter instilled, the mean values were $0.10 \mathrm{ml}$ for the preinjury samples, $0.19 \mathrm{ml}$ after FNLP treatment, $0.68 \mathrm{ml}$ after PMA treatment (Table I), and $0.07 \mathrm{ml}$ in control monkeys.

In order to insure that the lavage was obtained in areas of induced inflammation, Evan's Blue dye was included in the instillation of PMA or the second dose of FNLP. Blue dye was recovered to varying degrees in almost all BAL samples indicating that the areas lavaged had been exposed to the injurious agent.

Additional evaluation of the extent of injury was obtained by x-ray studies of the lungs before and after exposure to the inflammatory agents. All preexperiment chest radiographs were normal. Films taken $4.5 \mathrm{~h}$ after FNLP treatment or $3 \mathrm{~h}$ after PMA instillation, revealed patchy alveolar infiltrates, confined to a single lobe (Fig. 2). The remainder of the lung was clear. Additional $\mathrm{x}$-rays obtained $24 \mathrm{~h}$ later demonstrated the persistence of the infiltrate, and in some animals, an increase in density, consistent with early lobar consolidation.

In some animals open lung biopsies were taken $1 \mathrm{~h}$ after the second instillation of FNLP and 3-4 h after administration of PMA. The tissues revealed patchy accumulation of neutrophils in the alveolar septae and alveolar spaces. This was accompanied by modest amounts of protein-rich edema fluid (Fig. 1). These changes were considerably more severe in the monkeys treated with PMA.

Peripheral white blood cell counts, starting from an average of $6.0 \times 10^{3} / \mathrm{mm}^{3}$, rose in most cases, to an average of 17.1 $\times 10^{3} / \mathrm{mm}^{3} 5.5 \mathrm{~h}$ after FNLP treatment and to $12.5 \times 10^{3} / \mathrm{mm}^{3}$ $4 \mathrm{~h}$ after PMA challenge.

\section{Determination of protease activity in BAL fluid}

Assays of elastase activity on the synthetic substrate methoxysuc-ala-ala-pro-val-pNA of the BAL fluids were negative. To determine if neutrophil elastase was inactivated by binding to $\alpha_{1}$-PI, an ELISA technique was developed to measure the amount

Table I. Evidence of Pulmonary Injury

\begin{tabular}{lll}
\hline Stimulus & BAL fluid protein & $\begin{array}{l}\text { Lavage recovered per } \\
\text { ml instilled }\end{array}$ \\
\hline & $m g / m l$ & $m l$ \\
Untreated & $0.51 \pm 0.14(n=27)$ & $0.10 \pm .01(n=23)$ \\
Control & $0.85 \pm 0.24(n=8)$ & $0.07 \pm .01(n=8)$ \\
FNLP & $3.74 \pm 1.12(n=16)$ & $0.19 \pm .03(n=12)$ \\
PMA & $6.64 \pm 2.12(n=10)$ & $0.68 \pm .11(n=10)$
\end{tabular}

Data are expressed in this, and all subsequent tables, as mean \pm standard error of the mean.
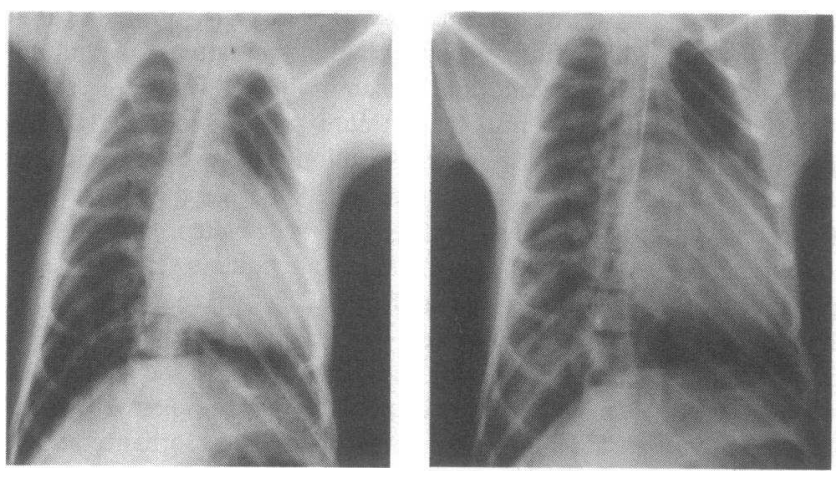

Figure 2. Chest radiographs of monkey before (left) and $3 \mathrm{~h}$ after (right) intrabronchial instillation of PMA. A patchy infiltrate can be seen in the right lower lobe after treatment.

of elastase- $\alpha_{1}$-PI complex in each lavage sample (see Methods). The mean value obtained in 13 BAL fluids of untreated monkeys was $0.47 \mu \mathrm{g} / \mathrm{ml}$. $11 \mathrm{BAL}$ samples taken at the end of the experimental period from animals treated with FNLP had an average elastase level of $0.99 \mu \mathrm{g} / \mathrm{ml}$. BAL fluid taken similarly from PMAtreated animals had an average of $1.23 \mu \mathrm{g} / \mathrm{ml}$ elastase complexed to $\alpha_{1}$-PI (Table II). To confirm that all the elastase present in the samples was complexed to $\alpha_{1}$-PI, duplicate ELISA assays were performed with additional monkey $\alpha_{1}$-PI added to each sample before assay. No significant increases were observed, indicating that all active elastase was already bound to $\alpha_{1}$-PI.

As assays of enzymatic activity in lavage fluids may not accurately reflect proteolytic activity in the bronchoalveolar space, we attempted to assess the presence of proteolytic activity in situ. To accomplish this, we instilled ${ }^{125} \mathrm{I}$-labeled PK as a probe of protease activity into the bronchoalveolar space $2 \mathrm{~min}$ before the lavage procedure. ${ }^{125} \mathrm{I}-\mathrm{PK}$ is cleaved by active Hageman factor, neutrophil elastase and other proteolytic enzymes. The ${ }^{125} \mathrm{I}$ PK recovered in the lavage fluid was subsequently analyzed on SDS-polyacrylamide gels for cleavage of the protein. The extent of cleavage was rated with a numerical value of $0-4$, with 0 reflecting no cleavage; 1 , up to $30 \%$ of the PK cleaved; $2, \sim 30$ $60 \%$ cleaved; $3, \sim 60-90 \%$ cleaved; and 4 , indicating complete disappearance of the native molecule. Representative samples are shown in Fig. 3.11 of 12 samples taken before injury showed 0 cleavage. After injury with FNLP or PMA, cleavage of PK was found to be variable. The average of FNLP-injured lung lavages was 1.5 while PMA-injured lung lavages had a mean cleavage value of 1.0 (Table II).

An attempt was made to assign specificity of the protease activity by including anti-elastase antibody with the radiolabeled PK in lavage samples taken from a different site in each animal. Although it could be shown in vitro that antibody to elastase could effectively block cleavage of PK induced by elastase, no consistent blockage was seen in vivo. As was the case in the absence of antibody, cleavage of PK in the presence of antibody was variable. (See representative samples in Fig. 3.) Again, rated on a scale of $0-4$, the average cleavage value of lavages performed in the presence of antibody to elastase in FNLP-treated animals was 0.75 and in PMA-injured animals was 1.1 (Table II). Cleavage patterns of PK as analyzed on SDS-polyacrylamide gels run in the presence or absence of $\beta$-mercaptoethanol differed from those obtained with purified neutrophil elastase in vitro but were 
Table II. Protease Activity in BAL Fluids

\begin{tabular}{|c|c|c|c|c|c|}
\hline & \multirow{2}{*}{$\begin{array}{l}\text { MNE complexed } \\
\text { to } \alpha_{1}-\mathrm{PI} \\
\mu g / m l B A L\end{array}$} & \multicolumn{2}{|l|}{ In situ cleavage of $\mathrm{PK}^{*}$} & \multirow{2}{*}{$\begin{array}{l}\text { Amidolytic activity§ } \\
\Delta A_{400} / \mathrm{h}\end{array}$} & \multirow[b]{2}{*}{$\beta$-Glucuronidase activit } \\
\hline & & $-A b \ddagger$ & $+A b \ddagger$ & & \\
\hline & & & & & $U / m l$ \\
\hline Untreated & $0.47 \pm .09(n=13)$ & $0.04 \pm .04(n=12)$ & - & - & $0.85 \pm 0.14(n=9)$ \\
\hline FNLP & $0.98 \pm 0.48(n=11)$ & $1.50 \pm .57(n=8)$ & $0.75 \pm .75(n=4)$ & $0.07 \pm .02(n=11)$ & $4.36 \pm 1.23(n=15)$ \\
\hline PMA & $1.22 \pm 0.73(n=10)$ & $1.00 \pm .63(n=5)$ & $1.1 \pm .25(n=5)$ & $0.22 \pm .08(n=8)$ & $8.25 \pm 3.05(n=10)$ \\
\hline
\end{tabular}

* 0 = no cleavage; 4 = complete cleavage (see text). $¥$ Antibody to elastase. $\S$ On substrate $H$-D-pro-phe-arg-pNA.

indistinguishable from patterns obtained by treatment of ${ }^{125} \mathrm{I}$ PK with active Hageman factor.

$50-\mu l$ samples of all the terminal lavage samples were assayed for amidolytic activity on the synthetic substrate $H$-D-pro-phearg pNA. Amidolytic activity of samples from FNLP- and PMAtreated animals is presented in Table II. To determine whether this activity was due to active Hageman factor, lavage samples were preincubated with corn inhibitor, a known specific inhibitor of Hageman factor activity (37). The amount of corn inhibitor used was sufficient to block an amount of $\mathrm{HFa}$ that would produce equal cleavage of the synthetic substrate as did BAL fluid. Partial inhibition was seen in most of the cases studied. Kallikrein is also capable of cleaving this synthetic substrate and an attempt was made to assess its potential presence in the lavage samples by the addition of SBTI, an inhibitor of kallikrein, to the samples prior to assay. The amount added was sufficient to block kallikrein in concentrations giving amidolysis equal to that seen with the BAL fluids. Again only partial inhibition was seen. Addition of corn inhibitor and SBTI together failed to block completely the amidolytic activity. It therefore appeared that a portion of the proteolytic activity was attributable to active Hageman factor and to an SBTI inhibitable protease, possibly kallikrein. An additional protease was also present.

The appearance of $\beta$-glucuronidase and myeloperoxidase in

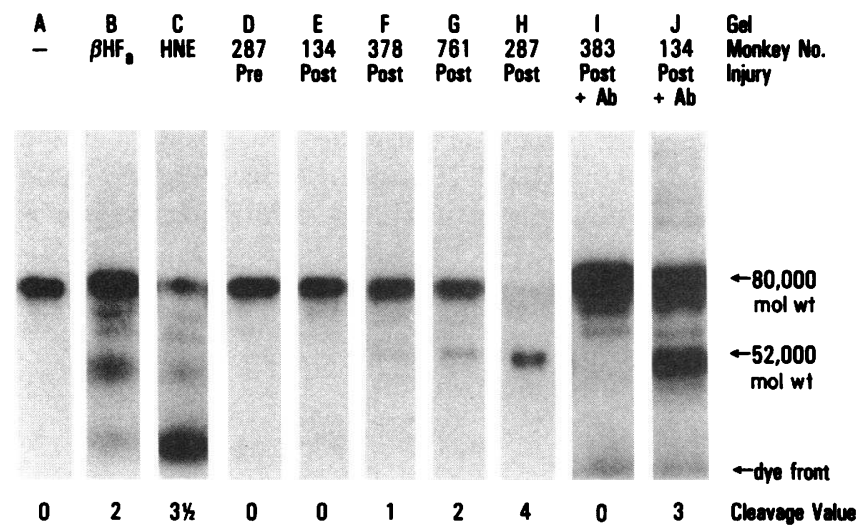

Figure 3. SDS-polyacrylamide gel of ${ }^{125} \mathrm{I}-\mathrm{PK}$ instilled into monkeys. All samples were reduced with $\beta$-mercaptoethanol prior to electrophoresis. Control gels on left show ${ }^{125}$ I-PK alone $(A)$ or with the addition of $\beta$-active Hageman factor $(B)$ or HNE $(C)$. Gel $D$ is the pattern obtained with 11 of the 12 untreated monkeys. The remaining gels are representative of post-injury samples in the absence $(E-H)$ or presence $(I, J)$ of antibody (Ab) to HNE. "Cleavage value" is described in text. the BAL fluids of untreated and FNLP- and PMA-treated animals was measured. $\beta$-glucuronidase was found to rise from 0.85 to $4.36 \mathrm{U} / \mathrm{ml}(P<0.04)$ and $8.25 \mathrm{U} / \mathrm{ml}(P<0.04)$, respectively (Table II). MPO, specific to neutrophils, showed a striking increase from $1.37 \mathrm{OD} \mathrm{U} / \mathrm{ml} \cdot \mathrm{min}$ in untreated to $16.59(P<0.1)$ and $30.47(P<0.001) \mathrm{OD} \mathrm{U} / \mathrm{ml} \cdot \mathrm{min}$ in FNLP- and PMAtreated samples (Table III). $50 \%$ of the control animals, which received saline and dilute DMSO, but no FNLP or PMA, showed elevated levels of $\beta$-glucuronidase activity after $5 \mathrm{~h}$. MPO activity was mildly elevated in one out of eight control samples.

Assessment of oxidant activity in pulmonary inflammation A diminished specific activity of $\alpha_{1}$-PI in BAL fluids has been used as an indicator of oxidant generation in vivo with inactive $\alpha_{1}$-PI at its native molecular weight in BAL fluids from human patients with respiratory distress syndrome being reactivated by exposure to reducing agents in the presence of MS peptide reductase (9). In the current experiments the specific activity of $\alpha_{1}$-PI was determined in the lavage samples taken before instillation of FNLP or PMA and in the BAL samples taken at the termination of the experiment. The specific activity of the $\alpha_{1-}$ PI fell from a mean of 0.80 in control samples to 0.57 and 0.65 with FNLP or PMA injury, respectively ( $P<0.06$ for both) (Table IV). In samples of four control animals, one showed no inhibition of $\alpha_{1}$-PI activity, two showed moderate inhibition (specific activities of 0.58 and 0.69 ) and one showed marked inhibition (specific activity of 0.32 ). An additional comparison was made utilizing plasma samples taken prior to or at the end of the injury period and analyzing the $\alpha_{1}$-PI specific activities in them. These values, also shown in Table IV, were 0.91, 0.89, and 0.86 for untreated, FNLP-treated, and PMA-treated animals,

Table III. Activities of Catalase and MPO in BAL Fluids

\begin{tabular}{|c|c|c|c|}
\hline & \multicolumn{2}{|l|}{ Catalase } & \multirow[b]{2}{*}{ MPO } \\
\hline & Total & $\begin{array}{l}\text { Specific } \\
\text { activity }\end{array}$ & \\
\hline & $\mu g / m l$ & & $\Delta O D_{414} / \mathrm{min} \cdot \mathrm{ml}$ \\
\hline Untreated $(n=19)$ & $0.37 \pm 0.08$ & $0.97 \pm 0.16$ & $1.37 \pm 0.55$ \\
\hline $\operatorname{FNLP}(n=9)$ & $0.70 \pm 0.22$ & $0.57 \pm 0.10$ & $16.59 \pm 12.91$ \\
\hline FNLP + AT $(n=6)$ & $0.34 \pm 0.05$ & $0.04 \pm 0.02$ & $0.85 \pm 0.38$ \\
\hline $\operatorname{PMA}(n=6)$ & $1.29 \pm 0.26$ & $1.08 \pm 0.20$ & $30.47 \pm 6.23$ \\
\hline $\mathrm{PMA}+\mathrm{AT}(n=4)$ & $1.44 \pm 1.17$ & $0.49 \pm 0.25$ & $0.60 \pm 0.37$ \\
\hline
\end{tabular}


Table IV. Specific Activity of $\alpha_{1}-P I$

\begin{tabular}{|c|c|c|c|c|}
\hline & \multicolumn{2}{|l|}{ BAL fluid } & \multicolumn{2}{|l|}{ Plasma } \\
\hline & Total & $\begin{array}{l}\text { Specific } \\
\text { activity }\end{array}$ & Total & $\begin{array}{l}\text { Specific } \\
\text { activity }\end{array}$ \\
\hline & $\mu g / m l$ & & $\mu g / m l$ & \\
\hline Untreated & $\begin{array}{l}12.9 \pm 4.3 \\
(n=11)\end{array}$ & $\begin{array}{l}0.80 \pm 0.04 \\
(n=11)\end{array}$ & $\begin{array}{l}1043 \pm 37.5 \\
(n=3)\end{array}$ & $\begin{array}{l}0.91 \pm 0.06 \\
(n=3)\end{array}$ \\
\hline FNLP & $\begin{array}{l}31.9 \pm 10.4 \\
(n=12)\end{array}$ & $\begin{array}{l}0.57 \pm 0.06 \\
(n=12)\end{array}$ & $\begin{array}{l}1504.7 \pm 80.3 \\
(n=8)\end{array}$ & $\begin{array}{l}0.89 \pm 0.04 \\
(n=8)\end{array}$ \\
\hline PMA & $\begin{array}{l}112.4 \pm 32.8 \\
(n=9)\end{array}$ & $\begin{array}{l}0.65 \pm 0.06 \\
(n=9)\end{array}$ & $\begin{array}{l}1088.4 \pm 70.4 \\
(n=4)\end{array}$ & $\begin{array}{l}0.86 \pm 0.02 \\
(n=4)\end{array}$ \\
\hline
\end{tabular}

respectively. These data suggest inactivation of $\alpha_{1}-\mathrm{PI}$ is occurring in the lung specifically.

To determine whether the observed inactivation of $\alpha_{1}-\mathrm{PI}$ was due to oxidative injury, we measured the increase in elastase inhibitory capacity of several BAL samples having specific activities of $<0.80$ after their incubation with the reducing agent DTT in the presence or absence of MS reductase. The results, presented in Table V, show complete reactivation of $\alpha_{1}-\mathrm{PI}$ in four out of five samples and partial restoration of activity in the fifth case. It is of interest to note that DTT alone resulted in significant, but not always complete, reactivation of the $\alpha_{1}$-PI in all cases.

The inactivation of catalase in sites of pulmonary inflammation in animals treated with aminotriazole has also been used as an indicator of oxidant $\left(\mathrm{H}_{2} \mathrm{O}_{2}\right)$ generation in vivo (13). In order to obtain values of specific activity, we measured total catalase in the lavage fluids immunologically using an ELISA assay and catalase activity by disappearance of $\mathrm{H}_{2} \mathrm{O}_{2}$ spectrophotometrically. Before injury, the average catalase specific activity of 19 lavage samples tested was 0.97 with the mean concentration being $0.37 \mu \mathrm{g} / \mathrm{ml}$. The average specific activities of the terminal lavage samples is given in Table III. With both FNLP and PMA-induced injury, a significant reduction $(P$

Table $V$. Reactivation of $\alpha_{1}-P I$ by Exposure to DTT $\pm M S$ Reductase

\begin{tabular}{|c|c|c|c|c|c|c|}
\hline Sample no. & $\begin{array}{l}\text { BAL } \\
1^{*}\end{array}$ & $\begin{array}{l}\text { BAL } \\
2\end{array}$ & $\begin{array}{l}\text { BAL } \\
3\end{array}$ & $\begin{array}{l}\text { BAL } \\
4\end{array}$ & $\begin{array}{l}\text { BAL } \\
5\end{array}$ & $\begin{array}{l}\text { Oxidized } \\
\text { NMP }\end{array}$ \\
\hline ‡ Sample alone (initial & 15 & 29.5 & 129 & 22.2 & 65 & \\
\hline ‡ Sample + DTT & 3.4 & 40.0 & 14.6 & 35.5 & 8.3 & 197.0 \\
\hline $\begin{array}{l}\text { ¥ Sample + DTT + MS } \\
\text { reductase }\end{array}$ & 6.3 & 49.1 & 27.0 & 34.8 & 9.9 & 715.8 \\
\hline $\begin{array}{l}\S \text { Total } \alpha_{1} \text {-PI protein in } \\
\text { sample }\end{array}$ & 12.5 & 52.2 & 24.5 & 28.8 & 10.6 & 1300.0 \\
\hline
\end{tabular}

All values are micrograms/milliliter.

* PMA injured, all others FNLP.

$¥$ Activity of $\alpha_{1}$-PI as determined by porcine elastase inhibition.

$\S$ Measured by radial immunodiffusion.
Table VI. Inhibition of MPO by AT in the Presence of $\mathrm{H}_{2} \mathrm{O}_{2}$

$\begin{array}{lc} & m U / m l \\ \mathrm{MPO} & 503 \\ \mathrm{MPO}+\mathrm{AT} & 484 \\ \mathrm{MPO}+\mathrm{AT}+\mathrm{H}_{2} \mathrm{O}_{2} & 8 \\ \mathrm{MPO}+\mathrm{H}_{2} \mathrm{O}_{2} & 210\end{array}$

$<0.001$ and $P<0.1)$ was seen in monkeys given aminotriazole. Specific activity for FNLP-treated animals fell from 0.57 to 0.04 and for PMA-treated animals from 1.08 to 0.49 . It is interesting to note that even in the absence of AT, there was a drop ( $P$ $<0.1)$ in specific activity of those animals receiving FNLP.

The inhibitory effect of AT in the presence of $\mathrm{H}_{2} \mathrm{O}_{2}$ extended to activity of myeloperoxidase as well. As shown in Table III, MPO activity fell from 16.59 to $0.85 \mathrm{OD} \mathrm{U} / \mathrm{min} \cdot \mathrm{ml}$ in the case of FNLP-injured BAL fluids when AT was added $(P=0.3)$ and from 30.47 to $0.60 \mathrm{OD} \mathrm{U} / \mathrm{min} \cdot \mathrm{ml}$ with PMA injury $(P<0.02)$. To determine whether this inhibition was dependent upon $\mathrm{H}_{2} \mathrm{O}_{2}$, studies were conducted in vitro which allowed for the slow diffusion of $\mathrm{H}_{2} \mathrm{O}_{2}$ into a solution of myeloperoxidase and aminotriazole (see Methods). As shown in Table VI, $>\mathbf{9 8 \%}$ of the MPO activity was inhibited by AT in the presence of $\mathrm{H}_{2} \mathrm{O}_{2}$ as compared to $<4 \%$ inhibition in its absence. An inhibition of $58 \%$ was seen using $\mathrm{H}_{2} \mathrm{O}_{2}$ diffusion in the absence of AT, but this effect did not occur when crude cell lysates were used as a source of MPO. These studies indicate that MPO inhibition by AT, like that of catalase, is dependent upon the presence of $\mathrm{H}_{2} \mathrm{O}_{2}$. The study validates the use of the inhibition of MPO by AT as an assay of $\mathrm{H}_{2} \mathrm{O}_{2}$ generation in the whole animal.

The level of the antioxidant glutathione was measured in the cell pellets recovered from the lavage samples to assess the possibility that increase in oxidant formation might be reflected by a decrease in intracellular antioxidants as is the case in our previous studies in rabbits (13). The results, shown in Table VII, suggest that this was not the case. Normalized to $\mathrm{mg}$ of cell protein, total glutathione levels were found to be variable, resulting in mean values not differing significantly $(P>0.4)$ from the untreated value of $37.5 \mathrm{nM} / \mathrm{mg}$. Treatment of the animals with AT did not appear to affect the glutathione levels $(P>0.4)$.

Leukotrienes. Assays were performed for detection of the leukotrienes $\mathrm{LTB}_{4}, \mathrm{LTC}_{4}, \mathrm{LTD}_{4}$ in 11 lavage samples. None were detected. The limits of sensitivity of the method would

Table VII. Glutathione Content of Cellular Component of Lavage Fluids

\begin{tabular}{ll}
\hline & $\begin{array}{l}\text { nmol/mg } \\
\text { cellular protein }\end{array}$ \\
\hline Untreated $(n=14)$ & $37.5 \pm 7.0$ \\
FNLP $(n=10)$ & $25.9 \pm 5.7$ \\
FNLP + AT $(n=6)$ & $33.7 \pm 5.0$ \\
PMA $(n=6)$ & $31.8 \pm 8.0$ \\
PMA + AT $(n=3)$ & $31.1 \pm 16.7$ \\
\hline
\end{tabular}


have allowed for the detection of $10 \mathrm{pmol} / \mathrm{ml}$ of $\mathrm{LTB}_{4}$ and 40 $\mathrm{pmol} / \mathrm{ml}$ of $\mathrm{LTC}_{4}$ or $\mathrm{LTD}_{4}$. Recovery of standards added to several lavage fluids, at the moment the lavage fluid was obtained, was from 74 to $100 \%$. In one sample, from an animal receiving FNLP, an unknown peak eluted from high performance liquid chromatography in the position corresponding to 15-hydroperoxyeicosa tetraenoic acid. The rate of metabolism or loss of leukotrienes in the tissues is not known.

$A C E$. The ACE level was compared in plasma samples taken at the beginning and end of the experiment in several of the monkeys. No significant differences were seen, with starting levels averaging $158.7 \mathrm{nmol}$ L-histadyl-L-leucine converted per min per $\mathrm{ml}$ of plasma and final values averaging 163.5.

\section{Discussion}

In these studies we utilized the rhesus monkey to establish an animal model of pulmonary inflammation and analyze the biochemical effector mechanisms responsible for the injury. Injury was induced by the intrabronchial instillation of the $\mathrm{N}$-formylated peptide, FNLP, or the phorbol ester, PMA. Control animals which received intrabronchial instillation of saline and diluted dimethyl sulfoxide were also studied. Plasma and BAL samples taken before and after inflammation developed served as the source of material for biochemical analyses of mediating systems potentially involved in the development of inflammation.

The control animals, receiving only saline and diluted dimethyl sulfoxide, which were included in these studies, showed little evidence of pulmonary inflammation although some biochemical evidence of changes appeared in some of the samples. It is not unreasonable to expect some response from repeated instillation of fluids and lavaging and the variability of the responses suggests that some animals are more sensitive than others. Several investigators have used repeated saline lavages as a method of inducing pulmonary inflammation $(47,48)$, although the volumes used were much greater than those used in the current studies. It is not our intent in these studies to prove that the inflammatory response invoked is entirely due to FNLP or PMA but rather to establish a model of pulmonary inflammation induced by a defined, reproducible, stimulus and mode of introduction into the animal.

The data show that the protocol used did induce moderate to severe pulmonary inflammation in the experimental animals (Table I). The amount of protein in the BAL fluids, as well as the quantity of fluid recovered, increased substantially. Mortality after PMA injury was $33 \%$ by $5 \mathrm{~h}$. None of the monkeys receiving FNLP died. X-rays of the lung fields revealed inflammatory infiltrates (Fig. 2), and histologic examination of open lung biopsies confirmed the presence of leukocytic infiltration (Fig. 1), which consisted of predominantly neutrophils at 4-6 $\mathrm{h}$ after instillation of FNLP or PMA, and mononuclear cells at 24 hours.

Analyses of the BAL fluid revealed the presence of both protease and oxidant activity. Studies to identify neutrophil elastase were prompted by the earlier findings of this enzyme in BAL fluids of patients with inflammatory disease of the lung $(3,6$, $10)$ and of the presence of leukocytic proteases in BAL fluids of rabbits (13). The immunologic assay described in this paper enabled us to detect from $0.04-5.5 \mu \mathrm{g} / \mathrm{ml}$ of neutrophil elastase, all of which was complexed to and inactivated by $\alpha_{1}$-PI. The concentration of $\alpha_{1}$-PI present in the BAL fluids was approxi- mately that which would be present due to the transudation of plasma proteins from the vascular space. It was possible that elastase, once secreted, remained bound to the cells and connective tissue lining the alveoli and was not removed by our lavaging procedure. This possibility is suggested by the relatively low levels of neutrophil elastase present in BAL fluids of stimulated monkeys compared with levels of myeloperoxidase and $\beta$-glucuronidase which are also constituents of the azurophil granules of neutrophils. It was for these reasons that we attempted to show protease activity in situ by instilling and retrieving ${ }^{125} \mathrm{I}$ labeled PK as a probe. The ${ }^{125} \mathrm{I}-\mathrm{PK}$ was instilled into two different lobes of each monkey, one in the presence of antibody to elastase (which could be shown in vitro to block to cleavage of ${ }^{125} \mathrm{I}-\mathrm{PK}$ by elastase) and one in the absence of antibody. Although good cleavage was seen in some samples, no statistical difference could be seen when antibody to neutrophil elastase was present (Fig. 3 and Table II). Furthermore, the pattern of cleavage fragments of the ${ }^{125}$ I-PK obtained was not the same as that seen with elastase in vitro. This was especially evident in samples run in the absence of the reducing agent $\beta$-mercaptoethanol (data not shown). Other enzymes, such as active Hageman factor (49-51) and a mastcell derived protease (52) are also known to cleave PK. The failure of the specific inhibitors from corn and soybean to completely inhibit the amidolytic activity of the BAL fluids suggests as well that multiple proteases are probably present.

The inability to detect active neutrophil elastase does not preclude its potential importance in mediating tissue injury in the lung. As noted in the previous paragraph, active elastase could be present, but bound to structures in the lung and less amenable to inhibition by $\alpha_{1}$-PI. In addition, neutrophils may well release elastase while adherent to connective tissue components of the lung in a position protected from $\alpha_{1}$-PI or the ${ }^{125} \mathrm{I}-\mathrm{PK}$ probe (a relatively large molecule that may not penetrate beneath adherent neutrophils). It should also be noted that in these short term experiments, i.e., $<6 \mathrm{~h}$ of inflammation as opposed to $>24 \mathrm{~h}$ in adult respiratory distress syndrome patients as an example, the $\alpha_{1}$-PI remains relatively active. It is altogether possible that oxidative inactivation of the $\alpha_{1}$-PI in the vicinity of leukocytes is greater than in more distant areas. This concept is supported by the complete oxidative inactivation of neutrophilic MPO seen in the presence of aminotriazole. Elastase at the point of release from leukocytes could therefore be protected from inactivation by $\alpha_{1}$-PI by this means as well.

Another way to facilitate the detection of elastase activity would be to block the $\alpha_{1}$-PI activity in vivo. This was done in six monkeys in the current studies (unpublished results) following published procedures $(16,53)$ in which the animals were given $50 \mathrm{mg} / \mathrm{kg} \mathrm{CT}$ intravenously daily for $7 \mathrm{~d}$ before injury with FNLP. On the day preceding and the day of the experiment, two additional CT injections were given since activity of the $\alpha_{1}$ $\mathrm{PI}$ in the monkey plasma before these final injections of CT was $>70 \%$ of normal. While levels of $\alpha_{1}$-PI activity then did approach $10 \%$ of normal, the surprising observation was made that the neutrophils in these monkeys had lost most of their elastase activity. CT could be shown in vitro to have no direct effect on neutrophil elastase. Why CT treatment should affect elastase levels in neutrophils in vivo is unclear.

Three methods were employed to monitor the production of oxidants in vivo. The first, measurement of the specific activity of $\alpha_{1}-\mathrm{PI}$, is based on the finding in recent years that a variety of biologically produced substances can cause oxidative inactivation 
of $\alpha_{1}$-PI $(9,14,15,19,39)$. Stimulated neutrophils have been shown to release such oxidants (54-57) and MPO, in the presence of $\mathrm{H}_{2} \mathrm{O}_{2}$ and halide has also been shown to cause inactivation of $\alpha_{1}$-PI (58). Studies showing the direct inactivation of $\alpha_{1}$-PI in the presence of PMA-stimulated human neutrophils and halide have been reported (17). In the studies reported here, significant inactivation of $\alpha_{1}$-PI did occur, with mean specific activities dropping from 0.80 in untreated animals to 0.57 and 0.65 in FNLP- and PMA-treated animals, respectively. The specific activity of $\alpha_{1}$-PI in plasma of treated and untreated monkeys ranged from 0.86 to 0.91 , suggesting that inactivation was occurring at the site of inflammation in the lung but not systemically. It is possible for $\alpha_{1}$-PI to become inactivated by means other than oxidation. Thiol proteases can cleave the molecule (59) and complexing with neutrophil elastase results in "inactive" $\alpha_{1}$-PI. While elastase- $\alpha_{1}$-PI complexes can be demonstrated in the present studies, the maximum quantity of $\alpha_{1}$-PI which might be involved is less than 4 percent. That the inactivation of $\alpha_{1}$ PI observed in these studies was, in fact, due to oxidation, was demonstrated by our ability to recover the activity by exposure of the partially inactive BAL samples to the reducing agent dithiothreitol in the presence of MS reductase. Full activity was recovered in four out of five cases (Table V) and partial recovery was observed in the fifth. Contrary to our previous studies using human $\alpha_{1}$-PI (9), partial reactivation was found to occur using DTT alone. This may represent a species difference or perhaps a true difference in the sensitivity of the oxidized $\alpha_{1}$-PI to reactivation. Normal monkey plasma oxidized with N-chlorosuccinimide showed $15 \%$ reactivation with DTT, which increased to $55 \%$ when the MS reductase was present.

A second method of oxidant detection was the inactivation of catalase (23), and, as shown in this paper, myeloperoxidase, which occurs in animals pretreated with AT when $\mathrm{H}_{2} \mathrm{O}_{2}$ is produced. In these studies, striking decreases in catalase specific activity were seen when AT-treated animals were injured with either FNLP or PMA (Table III). Because inhibition of catalase in AT-treated animals only occurs when $\mathrm{H}_{2} \mathrm{O}_{2}$ is present, these diminished specific activities constitute good evidence that oxidant is being produced. The more striking decrease in catalase specific activity in monkeys treated with FNLP + AT as opposed to PMA + AT could be a reflection of $(a)$ the shorter exposure of the PMA-treated monkeys to the stimulus ( $3 \mathrm{~h}$ as opposed to 5-6 h); (b) a greater loss of catalase into the extracellular milieu, presumably as a result of greater cell lysis; or $(c)$ the double exposure of FNLP monkeys to the stimulant, the second exposure being timed to react with leukocytes that enter the lung tissues at 4-5 $\mathrm{h}$ after the first exposure. It is interesting to note that even in the absence of AT, FNLP-treated animals showed a drop in catalase specific activity from 0.97 to 0.57 . The reasons for this are unclear, but it is possible that the catalase was inactivated by oxidants. It also appeared in these studies that levels of myeloperoxidase were greatly affected by pretreatment of the monkeys with AT (Table III). Although it would be reasonable to assume that the mechanism of inhibition might be similar to that of the catalase- $\mathrm{H}_{2} \mathrm{O}_{2}$-AT interaction, this had never been shown for MPO. We therefore conducted in vitro studies in which $\mathrm{H}_{2} \mathrm{O}_{2}$ was allowed to diffuse slowly into mixtures of MPO and AT and compared the residual MPO activity with that obtained with similar samples in which $\mathrm{H}_{2} \mathrm{O}_{2}$ was absent. The results (Table VI) clearly show the requirement for $\mathrm{H}_{2} \mathrm{O}_{2}$ for this inhibition.
The third method of oxidant detection that we used was measurement of intracellular glutathione levels. Participation of the glutathione oxidation-reduction cycle in antioxidant reactions would be reflected in decreased levels of glutathione intracellularly. Such decreases were not seen in these studies (Table VII). In similar studies done in rabbits (13), decreases in glutathione in lavaged alveolar cells were seen, although the decrease was not as dramatic as it was in whole lung tissue.

The establishment of a primate model for the study of pulmonary inflammatory injury is an important adjunct to studies usually performed in lower mammals. The ability to measure the generation in vivo of both proteases and oxidants as they appear during the development of pulmonary injury is essential to further studies and to the successful monitoring of the effects of various potential therapeutic agents.

\section{Acknowledgments}

The authors wish to acknowledge the expert assistance of Dr. Blaine Enderson, Dr. Ramarao Shankararao, and Dr. Laksman Sehgal, Ms. Hansa Sehgal, and Ms. Augustine Hunt-Coleman for their expert care and handling of the monkeys used in these studies. We thank also Dr. Manfred Schmitt for his help in the development of the ELISA assays, Dr. Ernest Beutler for his suggestion of a method for slow diffusion of $\mathrm{H}_{2} \mathrm{O}_{2}$ into a solution, Ms. Zenaida Oades for her help in performing $\mathrm{H}_{2} \mathrm{O}_{2}$ concentration determinations, Dr. Roger Spragg for his assistance in the statistical analyses, Dr. John Peters for his helpful discussions, and Mrs. Monica Bartlett for preparation of the manuscript.

These studies were supported by U. S. Public Health Service grants AI17354 and 2P50-23584, the Council for Tobacco Research (764I), and the Office of Naval Research (105-837).

\section{References}

1. Janoff, A., B. Sloan, G. Weinbaum, V. Damiano, R. A. Sandhaus, J. Elias, and P. Kimbel. 1977. Experimental emphysema produced by purified human neutrophil elastase. Tissue localization of the instilled protease. Am. Rev. Respir. Dis. 115:461-478.

2. Cochrane, C. G., and S. D. Revak. 1980. The participation of high molecular weight kininogen in hypotensive, shock and intravascular coagulation. Clin. Immunol. Immunopathol. 15:367-374.

3. Lee, C. T., A. M. Fein, M. Lippmann, H. Holtzman, P. Kimbel, and G. Weinbaum. 1981. Elastolytic activity in pulmonary lavage fluid from patients with adult respiratory distress syndrome. $N$. Engl. J. Med. 304:192-196.

4. O'Brodovich, H. M., S. A. Stalcup, L. M. Pang, J. S. Lipset, and R. B. Mellins. 1981. Bradykinin production and increased pulmonary endothelial permeability during acute respiratory failure in unanesthetized sheep. J. Clin. Invest. 67:514-522.

5. Johnson, K. J., J. C. Fantone III, J. Kaplan, and P. A. Ward. 1981. In vivo damage of rat lungs by oxygen metabolites. J. Clin. Invest. 671: 983-993.

6. McGuire, W. W., R. G. Spragg, A. B. Cohen, and C. G. Cochrane. 1982. Studies on the pathogenesis of the adult respiratory distress syndrome. J. Clin. Invest. 69:543-553.

7. Shasby, D. M., K. M. Vanbenthuysen, R. M. Tate, S. S. Shasby, I. McMurtry, and J. E. Repine. 1982. Granulocytes mediate acute edematous lung injury in rabbits and in isolated rabbit lungs perfused with phorbol myristate acetate: Role of oxygen radicals. Am. Rev. Respir. Dis. 125:443-447.

8. Till, G. O., K. J. Johnson, R. Kunkel, and P. A. Ward. 1982. Intravascular activation of complement and acute lung injury. Dependency on neutrophils and toxic oxygen metabolites. J. Clin. Invest. 69: 1126-1135. 
9. Cochrane, C. G., R. G. Spragg, and S. D. Revak. 1983. Studies on the pathogenesis of the adult respiratory distress syndrome: Evidence of oxidant activity in bronchoalveolar lavage fluid. J. Clin. Invest. 71: 754-761.

10. Merritt. T. A., C. G. Cochrane, K. Holcomb, B. Bohl, M. Hallman, D. Strayer, K. K. Edwards III, and L. Gluck. 1983. Elastase and $\alpha_{1^{-}}$ proteinase inhibitor activity in tracheal aspirates. Role of inflammation in the pathogenesis of bronchopulmonary dysplasia. J. Clin. Invest. 72: 656-666.

11. Ward, P. A., G. O. Till, R. Kunkel, and C. Beauchamp. 1983. Evidence for role of hydroxyl radical in complement and neutrophildependent tissue injury. J. Clin. Invest. 72:789-801.

12. Fligiel, S. E. G., P. A. Ward, K. J. Johnson, G. O. Till. 1984. Evidence for role of hydroxyl radicals in immune complex induced vasculitis. Am. J. Pathol. 115:375-382.

13. Schraufstatter, I. U., S. D. Revak, and C. G. Cochrane. 1984. Proteases and oxidants in experimental pulmonary inflammatory injury. J. Clin. Invest. 73:1175-1184.

14. Johnson, D., and J. Travis. 1978. Structural evidence for methionine at the reaction site of $\alpha$-1-proteinase inhibitor. J. Biol. Chem. 253:7142-7144.

15. Johnson, D., and J. Travis. 1979. The oxidative inactivation of human $\alpha$-1-proteinase inhibitor. Further evidence for methionine at the reactive center. J. Biol. Chem. 254:4022-4026.

16. Cohen, A. B. 1979. The effects in vivo and in vitro of oxidative damage to purified $\alpha_{1}$-antitrypsin and to the enzyme-inhibiting activity of plasma. Am. Rev. Resp. Dis. 119:953-960.

17. Zaslow, M. C., R. A. Clark, P. J. Stone, J. D. Calor, G. L. Snider, and C. Franzblau. 1983. Human neutrophil elastase does not bind to alpha ${ }_{1}$-protease inhibitor that has been exposed to activated human neutrophils. Am. Rev. Respir. Dis. 128:434-439.

18. Carp, H., and A. Janoff. 1978. Possible mechanisms of emphysema in smokers. Am. Rev. of Resp. Dis. 118:617-621.

19. Carp. H., F. Miller, J. R. Hoidal, and A. Janoff. 1982. Potential mechanism of emphysema: $\alpha 1$-proteinase inhibitor recovered from lungs of cigarette smokers contains oxidized methionine and has decreased elastase inhibitory capacity. Proc. Natl. Acad. Sci. USA. 79:2041-2045.

20. Hein, W. G., D. Appleman, and H. T. Pyfrom. 1956. Effects of 3-amino-1,2,4-triazole (AT) on catalase and other components. Am. J. Physiol. 186:19-26.

21. Margoliash, E., and A. Novogrodsky. 1958. A study of the inhibition of catalase by 3-amino-1:2:4-triazole. Biochem. J. 68:468-475.

22. Margoliash, E., A. Novogrodsky, and A. Schejter. 1960. Irreversible reaction of 3-amino-1:2:4 triazole and related inhibitors with the protein of catalase. Biochem. J. 74:339-348.

23. Sinet, P. M., R. E. Heikkela, and G. Cohen. 1980 . Hydrogen peroxide production by rat brain in vivo. J. Neurochem. 34:1421-1428.

24. McConahey, P. J., and F. J. Dixon. 1966. A method for trace iodination of proteins for immunologic studies. Int. Arch. Allergy Appl. Immunol. 29:185-193.

25. Stansell, M. J., and H. F. Deutsch. 1965. Preparation of crystalline erythrocuprein and catalase from human erythrocytes. J. Biol. Chem. 240:4299-4305.

26. Showell, H. J., R. J. Freer, S. H. Zigmond, E. Schiffmann, S. Aswanikumar, B. Corcoran, and E. L. Becker. 1976. The structure-activity relations of synthetic peptides as chemotactic factors and inducers of lysosomal enzyme secretion for neutrophils. J. Exp. Med. 143:11541169.

27. O'Flaherty, J. T., H. J. Showell, E. L. Becker, and P. A. Ward. 1978. Substances which aggregate neutrophils. Am. J. Pathol. 92:155166.

28. Zigmond, S. H. 1978. Chemotaxis by polymorphonuclear leukocytes. J. Cell. Biol. 77:269-287.

29. Freer, R. J., A. R. Day, J. A. Radding, E. Schiffmann, S. Aswanikumar, H. J. Showell, and E. L. Becker. 1980. Further studies on the structural requirements for synthetic peptide chemoattractants. Biochemistry. 19:2404-2410.
30. O'Flaherty, J. T., S. Cousart, A. S. Lineberger, E. Bond, D. A. Bass, D. Phil, L. R. De Chatelet, E. S. Leake, and C. G. McCall. 1980. Phorbol myristate acetate. In vivo effects upon neutrophils, platelets, and lung. Am. J. Pathol. 101:79-92.

31. Weissmann, G., J. E. Smolen, and H. M. Korchak. 1980. Release of inflammatory mediators from stimulated neutrophils. N. Engl. J. Med. 303:27-34.

32. Johnson, K. J., and P. A. Ward. 1982. Acute and progressive lung injury after contact with phorbol myristate acetate. Am. J. Pathol. 107:29-35.

33. Shasby, D. M., K. M. Vanbenthuysen, R. M. Tate, S. S. Shasby, I. McMurtry, and J. E. Repine. 1982. Granulocytes mediate acute edematous lung injury in rabbits and in isolated rabbit lungs perfused with phorbol myristate acetate: role of oxygen radicals. Am. Rev. Respir. Dis. 125:443-447.

34. Lowry, O. H., N. J. Rosebrough, A. L. Farr, and R. J. Randall. 1951. Protein measurement with the Folin phenol reagent. J. Biol. Chem. 193:265-275.

35. Aebi, H. 1974. Catalase. In Methods of Enzymatic Analysis. H. U. Bergmeyer, editor. Vol. 2. Academic Press, Inc., New York, 673684.

36. Fishman, W. H. 1965. In Methods of Enzymatic Analysis. H. U. Bergmeyer, editor. Academic Press, Inc., New York, 869-874.

37. Hojima, Y., J. V. Pierce, and J. J. Pisano. 1980. Hageman factor fragment inhibitor in corn seeds: purification and characterization. Thromb. Res. 20:149-162.

38. Mancini, G. A., A. O. Carbonas, and J. F. Heremans. 1965. Immunological quantitation of antigen by single radial immunodiffusion. Immunochemistry. 2:235-254.

39. Pannell, R., D. Johnson, and J. Travis. 1974. Isolation and properties of human plasma $\alpha$-1-proteinase inhibitor. Biochemistry. 13:54395445.

40. Abrams, W. R., G. Weinbaum, L. Weissbach, H. Weissbach, and N. Brot. 1981. Enzymatic reduction of oxidized $\alpha$-1-proteinase inhibitor restores biological activity. Proc. Natl. Acad. Sci. USA. 78:74837486.

41. Brehe, J. E., and H. B. Burch. 1976. Enzymatic assay for glutathione. Anal. Biochem. 74:189-197.

42. Laemmli, U. K. 1970. Cleavage of structural proteins during the assembly of the head of bacteriophage $\mathrm{T}_{4}$. Nature (Lond.). 227:680-685.

43. Clancy, R. M., and T. E. Hugli. 1983. The extraction of leukotrienes $\left(\mathrm{LTC}_{4}, \mathrm{LTD}_{4}\right.$ and $\left.\mathrm{LTE}_{4}\right)$ from tissue fluids: the metabolism of these mediators during IgE-dependent hypersensitivity reactions in lung. Anal. Biochem. 133:30-39.

44. Friedlund, J., and E. Silverstein. 1976. A sensitive fluorimetric assay for angiotensin-converting enzyme. Am. J. Clin. Pathol. 66:416424.

45. Cohen, G., and P. Hochstein. 1961. Glucose-6-phosphate dehydrogenase and detoxification of hydrogen peroxide in human erythrocytes. Science (Wash. DC). 134:1756-1757.

46. Hyslop, P. A., and L. A. Sklar. 1984. A quantitative fluorimetric assay for the determination of oxidant production by polymorphonuclear leukocytes: its use in the simultaneous fluorimetric assay of cellular activation processes. Anal. Biochem. 141:280-286.

47. Kazmierowski, J. A., J. I. Gallin, and H. Y. Reynolds. 1977. Mechanism for the inflammatory response in primate lungs. Demonstration and partial characterization of an alveolar macrophage-derived chemotactic factor with preferential activity for polymorphonuclear leukocytes. J. Clin. Invest. 59:273-281.

48. Damiano, V. V., A Cohen, A. L. Tsang, G. Batra, and R. Petersen. 1980. A morphologic study of the influx of neutrophils into dog lung alveoli after lavage with sterile saline. Am. J. Pathol. 100:349-354.

49. Kaplan, A. P., and K. F. Austen. 1970. A prealbumin activator of prekallikrein. J. Immunol. 105:802-811.

50. Wuepper, K. D., and C. G. Cochrane. 1972. Plasma prekallikrein: Isolation, characterization, and mechanism of activation. J. Exp. Med. 135:1-20. 
51. Bouma, B. N., L. A. Miles, G. Beretta, and J. H. Griffin. 1980. Human plasma prekallikrein. Studies of its activation by activated Factor XII and of its inactivation by diisopropyl phosphofluoridate. Biochemistry. 19:1151-1160.

52. Meier, H. L., A. P. Kaplan, L. M. Lichtenstein, S. Revak, C. G. Cochrane, and H. H. Newball. 1983. Anaphylactic release of a prekallikrein activator from human lung in vitro. J. Clin. Invest. 72:574-581.

53. Abrams, W. R., A. B. Cohen, V. V. Damiano, A. E. Eliraz, P. Kimbel, D. R. Meranze, and G. Weinbaum. 1981. A model of decreased functional $\alpha$-1-proteinase inhibitor. J. Clin. Invest. 68:1132-1139.

54. Babior, B. M., R. Kipnes, and J. Curmutte. 1973. Biological defense mechanisms. The production by leukocytes of superoxide, a potential bactericidal agent. J. Clin. Invest. 52:741-744.

55. Goldstein, I. M., D. Roos, H. B. Kaplan, and G. Weissmann. 1975. Complement and immunoglobulins stimulate superoxide pro- duction by human leukocytes independently of phagocytosis. J. Clin. Invest. 56:1155-1163.

56. Klebanoff, S. J., and H. Rosen. 1978. Ethylene formation by polymorphonuclear leukocytes. Role of myeloperoxidase. J. Exp. Med. 148:490-506.

57. Carp, H., and A. Janoff. 1979. In vitro suppression of serum elastase-inhibitory capacity by reactive oxygen species generated by phagocytosing polymorphonuclear leukocytes. J. Clin. Invest. 63:793797.

58. Matheson, N. R., P. S. Wong, and J. Travis. 1979. Enzymatic inactivation of alpha-1-proteinase inhibitor by neutrophil myeloperoxidase. Biochem. Biophys. Res. Commun. 88:402-409.

59. Johnson, D., and J. Travis. 1977. Inactivation of human alpha1-proteinase inhibitor by thiol proteinases. Biochem. J. 163:639-641. 